\title{
Tolbutamide Stimulation and Inhibition of Insulin Release: Studies of the Underlying Ionic Mechanisms in Isolated Rat Islets
}

\author{
J.-C. Henquin \\ Unité de Diabète et Croissance, University of Louvain School of Medicine, Brussels, Belgium
}

\begin{abstract}
Summary. The effects of tolbutamide on insulin release, ${ }^{45} \mathrm{Ca}^{2+}$ uptake and ${ }^{86} \mathrm{Rb}^{+}$efflux were studied in isolated rat islets. At a low glucose concentration $(75 \mathrm{mg} / \mathrm{dl})$, tolbutamide $(20-500 \mu \mathrm{g} / \mathrm{ml})$ produced a rapid, dose-dependent increase in insulin release from perifused islets. After $30-40 \mathrm{~min}$ however, the rate of secretion as well as the potentiating effect of theophylline were inversely related to the concentration of sulphonylurea. The monophasic release of insulin triggered by tolbutamide $(100 \mu \mathrm{g} / \mathrm{ml})$ at low glucose could be evoked again by removing and reintroducing the drug, or by temporarily withdrawing calcium or adding cobalt to the medium. Tolbutamide $(20 \mu \mathrm{g} / \mathrm{ml})$ accelerated and potentiated the biphasic insulin release in response to a secondary stimulation by glucose $(150 \mathrm{mg} / \mathrm{dl})$. By contrast, $100 \mu \mathrm{g} / \mathrm{ml}$ tolbutamide reduced the releasing effect of glucose to a slow increase in secretion rates.
\end{abstract} Theophylline normalized the second phase of release, but did not restore the rapid phase. Tolbutamide stimulated ${ }^{45} \mathrm{Ca}^{2+}$ influx ( 2 min-uptake) in islet cells; this effect was maximum immediately after addition of the drug and decreased later on, exhibiting a monophasic pattern. Glucose stimulation of $\mathrm{Ca}^{2+}$ uptake $(5 \mathrm{~min})$ was reduced in the presence of $100 \mu \mathrm{g} / \mathrm{ml}$ tolbutamide. At a low glucose concentration, tolbutamide reversibly reduced ${ }^{86} \mathrm{Rb}^{+}$efflux (tracer of $\mathrm{K}^{+}$) from islet cells, without altering the further inhibition of this efflux by a later glucose increase. It is suggested that tolbutamide depolarizes B cells partially by reducing their $\mathrm{K}^{+}$permeability. This depolarization leads to opening of voltagedependent calcium channels and the resulting $\mathrm{Ca}^{2+}$ influx triggers insulin release. The important and maintained depolarization by high concentrations of tolbutamide may secondarily inactivate these channels and cause a decrease in $\mathrm{Ca}^{2+}$ influx. This could explain the monophasic release of insulin and the refractoriness of B cells to subsequent glucose stimulation.

Key words: Isolated rat islets, tolbutamide, insulin release, glucose metabolism, rubidium efflux, calcium uptake, glucose, theophylline, cobalt, potassium.

Sulphonylureas have been used for more than twenty years to treat diabetic patients, but, despite intensive investigation, the mechanisms by which they decrease blood glucose levels are not completely understood. The role of the pancreas in the hypoglycaemic action of sulphonylureas has been established by the pioneer work of Loubatières [1] and was confirmed by the demonstration that these drugs stimulate insulin release in man [2] and animals [3] by a direct effect on $\mathrm{B}$ cells demonstrated in vitro [4]. This insulinotropic action of acute administration of sulphonylureas has since been extensively studied; its characteristics and possible mechanisms have been the subject of several reviews [5-8]. Many clinical investigations have failed, however, to show a correlation between the lowering of blood glucose and an increase in plasma insulin levels after chronic treatment with sulphonylureas [9-11]. These latter observations have been related to unexplained reports showing that after long-term treatment of animals with sulphonylureas, the in vivo and in vitro insulin response to glucose was reduced [12-15].

The present study carried out with isolated rat islets, was designed to explore in detail the mechanisms underlying the secretory and related ionic changes produced in B cells by tolbutamide. 

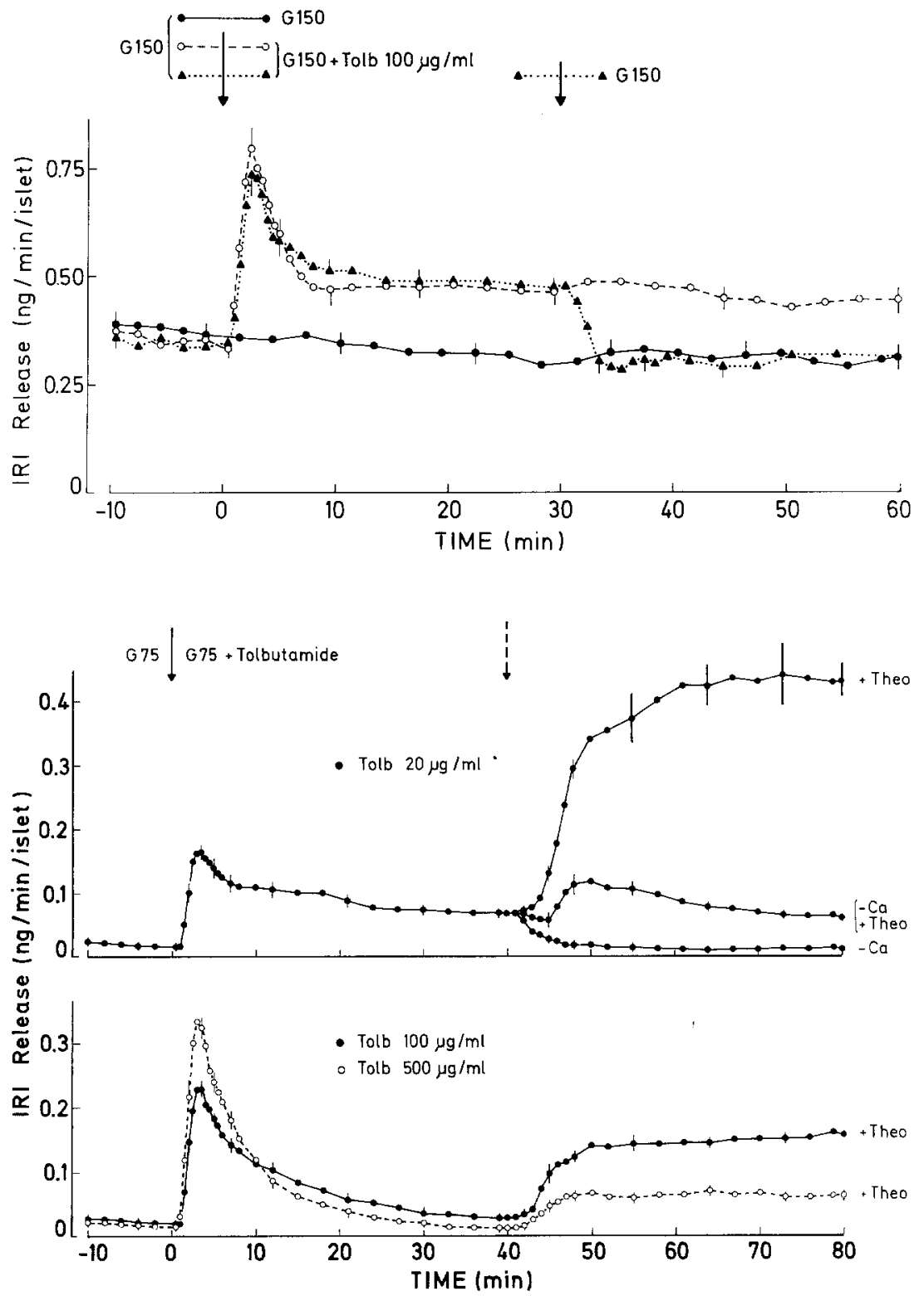

Fig. 1. Kinetics of tolbutamide effect on immunoreactive insulin (IRI) release from isolated rat islets perifused in the presence of $150 \mathrm{mg}$ glucose/dl. After an initial washing period of $30 \mathrm{~min}(\mathrm{~min}-30$ to 0$)$, tolbutamide $(100 \mu \mathrm{g} / \mathrm{ml})$ was added to the medium for $30(\boldsymbol{\Lambda} \ldots \boldsymbol{\Lambda})$ or for 60 $(0--0) \mathrm{min}$. The control release of insulin by islets perifused with glucose alone is also shown (-). Values are means \pm SEM of 4 experiments
Fig. 2. Kinetics of the effect of tolbutamide alone, or in combination with theophylline on immunoreactive insulin (IRI) release from rat islets perifused in the presence of $75 \mathrm{mg}$ glucose/dl. At min 0 , tolbutamide was added at the indicated concentration and remained present until the end of the experiments. At min 40 (broken arrow), $2 \mathrm{mmol} / \mathrm{l}$ theophylline ( + Theo) was added and/or extracellular calcium was removed $(-\mathrm{Ca})$, as indicated in the right part of the Figure. In upper panel, values are means \pm SEM of 9 experiments until min 40 and of 3 experiments thereafter. In lower panel, values are means \pm SEM of 4 experiments

\section{Methods}

\section{Animals and Solutions}

All experiments were performed with islets isolated from fed male Wistar rats $(275-325 \mathrm{~g})$ decapitated $3 \mathrm{~h}$ after intraperitoneal injection of pilocarpine $(20 \mathrm{mg} / \mathrm{kg}$ ) [16]. Blood was collected from the neck-vessels in 25 of the animals used. Plasma glucose determined by a glucose oxidase method (Beckman Instruments Inc., Fullerton, Calif.) and immunoreactive insulin levels were $127 \pm$ $3 \mathrm{mg} / \mathrm{dl}$ and $2.2 \pm 0.2 \mathrm{ng} / \mathrm{ml}$, respectively (mean $\pm \mathrm{SEM}$ ). The islets were obtained by combining mild collagenase digestion of the gland $(5 \mathrm{mg}$ collagenase per pancreas and shaking for 3.5-4 min) and microdissection of the partially digested pieces.

The medium utilized was a Krebs-Ringer bicarbonate buffer, $\mathrm{pH} 7.4$, gassed with $\mathrm{O}_{2} / \mathrm{CO}_{2}(94: 6)$, with the following ionic composition (mmol/l): $\mathrm{NaCl}, 118 ; \mathrm{KCl}, 4.8 ; \mathrm{CaCl}_{2}, 2.5 ; \mathrm{MgSO}_{4}, 1.2$; $\mathrm{KH}_{2} \mathrm{PO}_{4}, 1.2 ; \mathrm{NaHCO}_{3}, 25$ and supplemented with $0.5 \mathrm{~g} / \mathrm{dl} /$ bovine serum albumin. When not otherwise indicated, it also contained $50 \mathrm{mg}$ glucose/dl. When $\mathrm{CaCl}_{2}$ was omitted or $\mathrm{KCl}$ increased, appropriate changes were made in $\mathrm{NaCl}$ to maintain isosmolarity. When $\mathrm{CoCl}_{2}$ was added, $\mathrm{KH}_{2} \mathrm{PO}_{4}$ was replaced by $\mathrm{KCl}$ to avoid precipitation of cobalt salts. For measurements of ${ }^{45} \mathrm{Ca}$ uptake and glucose utilization, $10 \mathrm{mmol} / 1 \mathrm{HEPES}$ (N-2-hydroxyethylpiperazine- $\mathrm{N}^{2}$-2-ethanesulphonic acid) was added to the medium to prevent any change of $\mathrm{pH}$ in the small volumes of solutions used in these experiments.

\section{Measurements of Insulin Release, Glucose Utilization and Rubidium Efflux}

The perifusion technique utilized to study the dynamics of insulin release and the method for measurement of immunoreactive insulin (with rat insulin as standard) have been described previously [17]. No experimental modification of the medium interfered with the immunoassay. 
Glucose utilization by islet cells was measured by the production of $\left[{ }^{3} \mathrm{H}\right]$ water from $\mathrm{D}-\left[5-{ }^{3} \mathrm{H}\right]$ glucose [18]. The technical aspects of the method have been published [19].

The technique to monitor the efflux of ${ }^{86} \mathrm{Rb}^{+}$(used as tracer of $\mathrm{K}^{+}$) from preloaded islets has been described in detail [20, 21]. In this system complete washout of an extracellular marker, $\left[{ }^{3} \mathrm{H}\right] \mathrm{su}-$ crose, takes about 8 to $10 \mathrm{~min} .{ }^{86} \mathrm{Rb}^{+}$in the effluent fractions (collected after the 20th min) and remaining in the islets at the end of the experiment was counted by the Cerenkov radiation [21]. For each collection interval the fractional efflux of ${ }^{86} \mathrm{Rb}^{+}\left({ }^{86} \mathrm{Rb}^{+}\right.$ released during the time interval/ ${ }^{86} \mathrm{Rb}^{+}$remaining in the tissue during that time interval) was calculated.

\section{Measurements of Calcium Uptake}

${ }^{45} \mathrm{Ca}^{2+}$ uptake was studied in relation to that of $\left[6,6^{\prime}-{ }^{3} \mathrm{H}\right]$ sucrose, which is restricted to the extracellular space of isolated islets [22]. The technique has been simplified since our initial description [17]. Incubations were carried out in polypropylene tubes (vol $0.4 \mathrm{ml}$; Milian Instruments S.A., Geneva) containing $200 \mu \mathrm{l}$ of silicone oil (Versilube F 50). After preincubation, batches of 10 islets were transferred into $50 \mu \mathrm{l}$ medium $\left(2.5 \mathrm{mmol} / 1 \mathrm{CaCl}_{2}\right)$ layered on silicone oil. The uptake period was started by adding $50 \mu \mathrm{l}$ of medium supplemented with ${ }^{45} \mathrm{CaCl}_{2}(26 \mathrm{mCi} / \mathrm{mmol}, 0.96 \mathrm{GBq} /$ $\mathrm{mmol})$ and $1 \mathrm{mmol} / 1\left[6,6^{\prime}-{ }^{3} \mathrm{H}\right]$ sucrose $(40 \mathrm{mCi} / \mathrm{mmol}, 1.48 \mathrm{GBq} /$ $\mathrm{mmol}$ ) and terminated by centrifugation of the islets through the layer of silicone (10 s at $15,000 \mathrm{rpm}$ in a Microfuge, Beckman). The bottom of the tubes was then cut, the radioactivity contained in the pellet of islets counted and the amount of $\mathrm{Ca}^{2+}$ taken up by the tissue calculated as described previously [17]. Incubation tubes and media, the composition of which is detailed in the legends to the figures, were always prewarmed at $37^{\circ} \mathrm{C}$ before starting the experiments. Blanks without islets were run for all experimenta conditions and never differed from the background of the counter.

\section{Chemicals}

Tolbutamide (free acid form, batch D105) was kindly supplied by Farbwerke Hoechst, A.G., Frankfurt, Germany. A stock solution of $15 \mathrm{mg} / \mathrm{ml}$ in $0.1 \mathrm{~mol} / 1 \mathrm{NaOH}$ was prepared each day and aliquots were added to the test solutions before each experiment. ${ }^{86} \mathrm{RbCl}(0.33 \mathrm{Ci} / \mathrm{mmol}, 12.2 \mathrm{GBq} / \mathrm{mmol}),{ }^{45} \mathrm{CaCl}_{2}(1.1 \mathrm{Ci} / \mathrm{mmol}$, $41 \mathrm{GBq} / \mathrm{mmol}),\left[6,6{ }^{3} \mathrm{H}\right]$ sucrose $(3 \mathrm{Ci} / \mathrm{mmol}, 111 \mathrm{GBq} / \mathrm{mmol})$ and $\left[5-{ }^{3} \mathrm{H}\right]$ glucose $(1 \mathrm{Ci} / \mathrm{mmol}, 37 \mathrm{GBq} / \mathrm{mmol})$ were obtained from the Radiochemical Centre, Amersham, Bucks, U.K.; HEPES was from British Drug Houses, Poole, Dorset, U.K.; Versilube F50 was from General Electric Silicones Europe, Bergen op Zoom, Netherlands; Collagenase type IV (200 U/mg) was from Worthington Biochemical Co., Freehold, N.J. All other reagents were of analytical grade and purchased from Merck A.G., Darmstadt, Germany.

\section{Presentation of Results}

Results are presented as means \pm SEM and the statistical significance of differences between experimental groups was assessed by the nonparametric Wilcoxon rank-sum test.

\section{Results}

\section{Kinetics of Tolbutamide-stimulated Insulin Release}

In the presence of $150 \mathrm{mg}$ glucose $/ \mathrm{dl}(\mathrm{G} \mathrm{150})^{1}$, $100 \mu \mathrm{g}$ tolbutamide/ml (T 100) ${ }^{1}$ rapidly augmented the release of insulin stimulated by the sugar in peri-
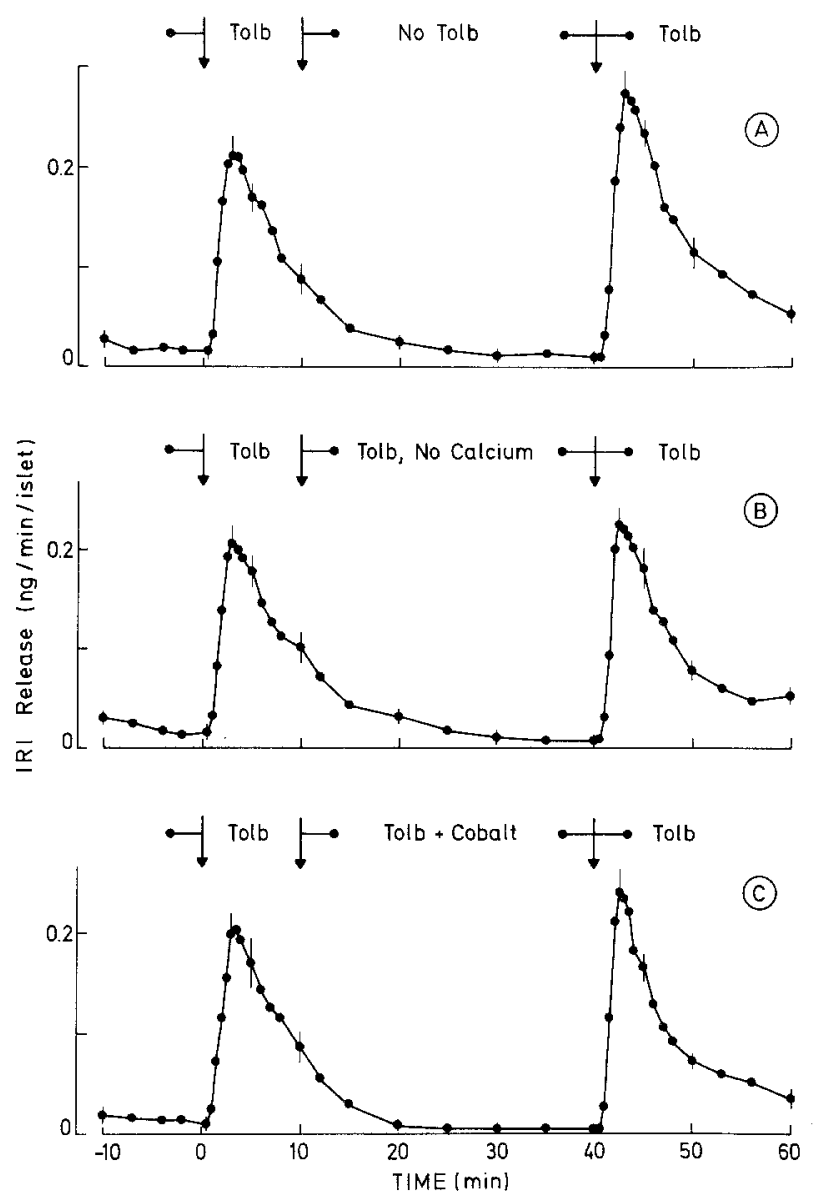

Fig. 3. Reactivation of tolbutamide stimulation of immunoreactive insulin (IRI) release from rat islets perifused in the presence of $75 \mathrm{mg}$ glucose $/ \mathrm{dl}$. Tolbutamide $(100 \mu \mathrm{g} / \mathrm{ml})$ was added to the medium at min 0 . In $\mathrm{A}$, it was withdrawn at min 10 and reintroduced at min 40 . In $B$, tolbutamide remained present throughout, but extracellular $\mathrm{Ca}^{2+}$ was withdrawn at min 10 and reintroduced at $\min 40$. In $\mathrm{C}$, tolbutamide remained present throughout, but cobalt $(2 \mathrm{mmol} / \mathrm{l})$ was added at $\mathrm{min} 10$ and withdrawn at min 40 . Values are means \pm SEM of 5 experiments

fused rat islets (Fig. 1). The effect of the sulphonylurea persisted as long as the drug remained present in the medium and was fully and promtly reversible upon its withdrawal.

The potency of tolbutamide was markedly dependent on the prevailing glucose concentration: T 100 increased insulin release above the effect of glucose alone by $4.64 \pm 0.37,2.22 \pm 0.17$ and 0.40 $\pm 0.05 \mathrm{ng} / 30 \mathrm{~min}$ per islet at $\mathrm{G} 150, \mathrm{G} 75$ and $\mathrm{G} 0$, respectively $(\mathrm{n}=8)$. The kinetics of tolbutamidestimulated insulin release was also modified by glu-

1 Abbreviations used in this paper: $\mathrm{G} 0$ : no glucose; G 75, G 150 and $\mathrm{G} 300$ : glucose 75,150 and $300 \mathrm{mg} / \mathrm{dl}$, respectively; $\mathrm{T} 0$ : no tolbutamide; T 20, T 100 and T 500: tolbutamide 20, 100 and $500 \mu \mathrm{g} / \mathrm{ml}$, respectively 


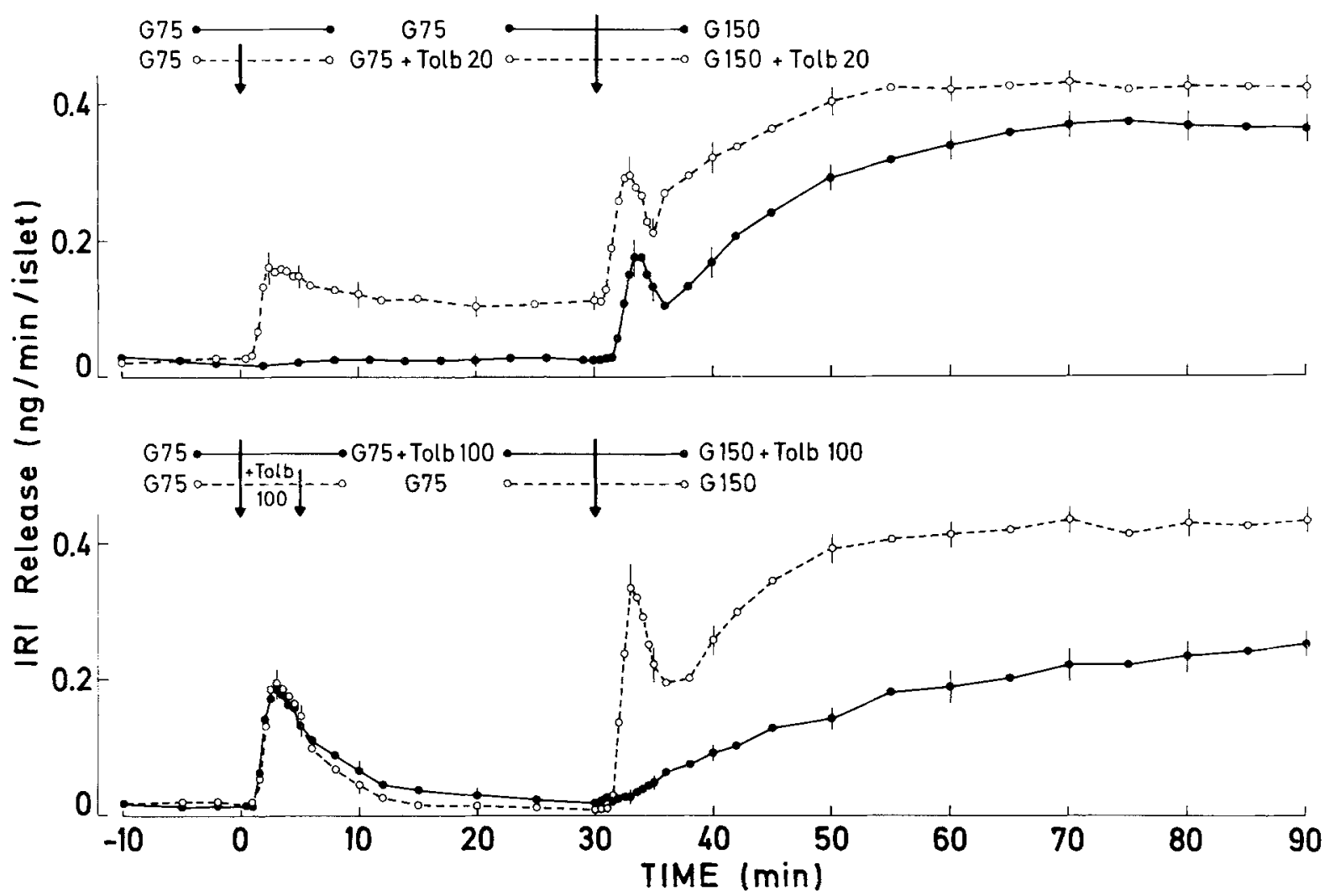

Fig. 4. Effect of tolbutamide on the kinetics of a subsequent glucose stimulation of immunoreactive insulin (IRI) release from perifused rat islets. The glucose concentration was increased from 75 to $150 \mathrm{mg} / \mathrm{dl}$ from $\mathrm{min} 30$ to 90 . Upper panel illustrates the response of control islets (-) and of islets stimulated with $20 \mu \mathrm{g}$ tolbutamide $/ \mathrm{ml}$ from $\mathrm{min} 0$ to $90(\mathrm{O}--\mathrm{O})$. In lower panel, tolbutamide $(100 \mu \mathrm{g} / \mathrm{ml})$ was added from min 0 to $90(-\infty)$ ) or only from min 0 to $5(0---0)$. Values are means \pm SEM of 6 experiments

cose. The late phase of sustained release seen at G 150 (Fig. 1) was markedly reduced at G 75 (Fig. 2 lower panel) and absent at $\mathrm{G} 0$. In addition, as illustrated by Figure 2, the pattern of insulin release stimulated by tolbutamide at $\mathrm{G} 75$ was also dependent on the concentration of the sulphonylurea. The maximum rate of release (at $\min 3-3.5$, including $45 \mathrm{sec}$ of dead time) increased with the concentration of tolbutamide $(20-500 \mu \mathrm{g} / \mathrm{ml})$. By contrast, after $30-40 \mathrm{~min}$, the rate of insulin release was inversely related to the concentration of the drug.

\section{Effect of Theophylline on Tolbutamide-stimulated Insulin Release}

The purpose of the experiments illustrated in the right part of Figure 2 was not to confirm the potentiation by methylxanthines of the immediate releasing effect of tolbutamide [7], but to investigate whether theophylline could increase the rate of release after it had already declined. It is evident that the increase in insulin release recorded upon addition of theophylline was inversely related to the concentration of tol- butamide, i.e. directly related to the rate of secretion still induced by the sulphonylurea when the methylxanthine was added. Finally, the upper panel of Figure 2 also shows that the late phase of insulin release stimulated by $\mathrm{T} 20$ depends on the presence of extracellular $\mathrm{Ca}^{2+}$ and that, in absence of this cation, theophylline had a considerably reduced effect.

\section{Reactivation of Tolbutamide Stimulation of Insulin Release}

In the experiments shown in Figure 3, an attempt was made to overcome the delayed inactivation of insulin release produced by tolbutamide. If $\mathrm{T} 100$ was added to the perifusate for $10 \mathrm{~min}$ and withdrawn for $30 \mathrm{~min}$, its readmission stimulated insulin secretion (Fig. $3 \mathrm{~A}$ ). When $\mathrm{Ca}^{2+}$ was removed $10 \mathrm{~min}$ after stimulation with $\mathrm{T} 100$, while the sulphonylurea remained present, its reintroduction in the medium was sufficient to trigger insulin release (Fig. 3 B). The same effect could be produced without withdrawing extracellular $\mathrm{Ca}^{2+}$ by temporarily preventing its 


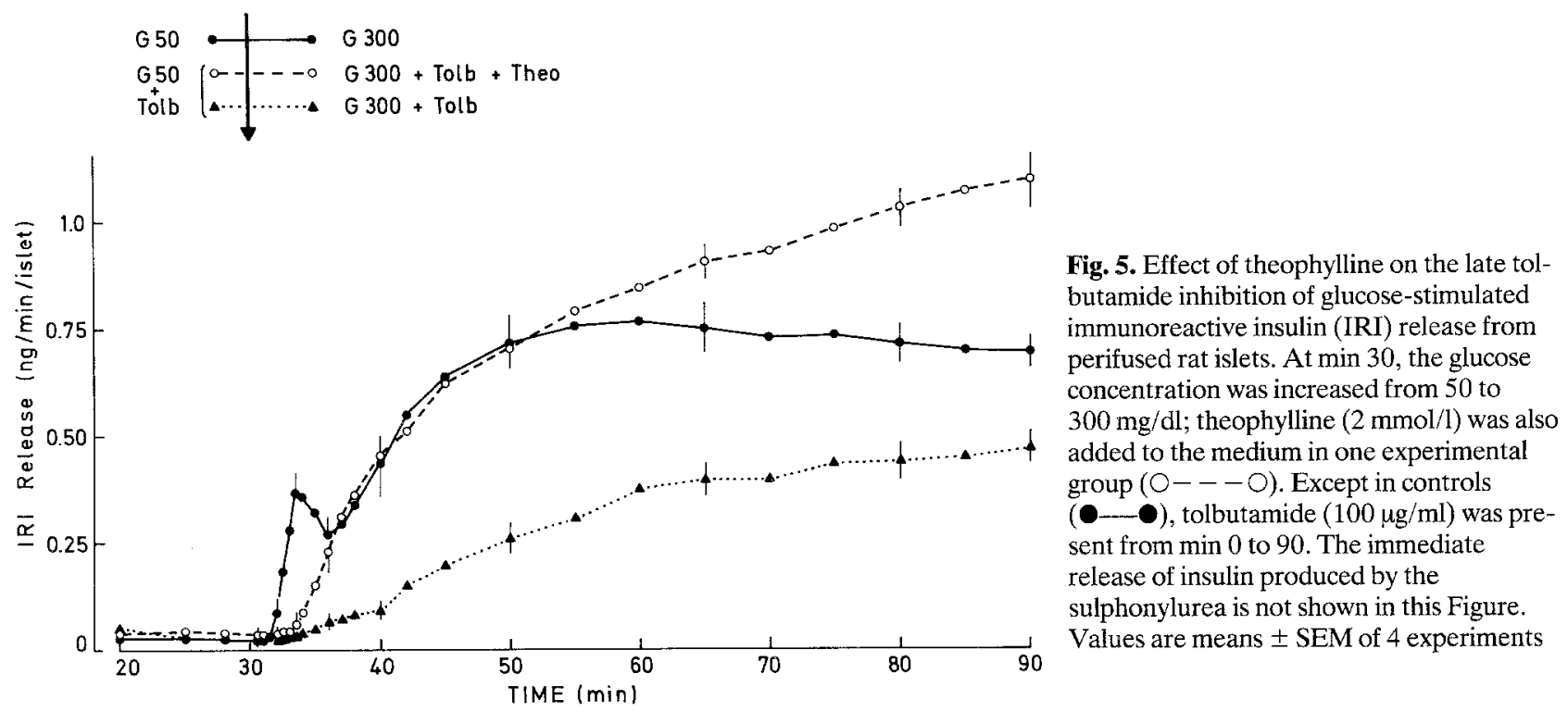

entry in B cells [17] with cobalt (Fig. 3 C). Similar experiments did not change basal insulin release recorded at $\mathrm{G} 75$ in the absence of tolbutamide (not shown).

\section{Effects of Tolbutamide on Potassium-stimulated Insulin Release}

At G 75, initial stimulation with $\mathrm{T} 100$ prevented, almost completely, high $\mathrm{K}^{+}(48 \mathrm{mmol} / 1)$ from inducing insulin release (high $\mathrm{K}^{+}$after T100: $0.05 \pm$ $0.02 \mathrm{ng} / 30 \mathrm{~min}$ per islet; high $\mathrm{K}^{+}$alone: $1.84 \pm$ $0.16 \mathrm{ng} / 30 \mathrm{~min}$ per islet; $\mathbf{n}=5$ ). Similarly, an initial stimulation with high $\mathrm{K}^{+}$abolished the releasing effect of a subsequent challenge with T 100 (T 100 after high $\mathrm{K}^{+}$: not detectable; T 100 alone: $2.10 \pm$ $0.16 \mathrm{ng} / 30 \mathrm{~min}$ per islet; $\mathrm{n}=5$ ). These effects were independent of the amount of insulin released during the first stimulation, since they were also observed in $\mathrm{G} 0$, when the control insulin response to $\mathrm{T} 100$ or $48 \mathrm{mmol} / 1 \mathrm{~K}^{+}$is markedly reduced.

\section{Effects of Tolbutamide \\ on Glucose-stimulated Insulin Release}

The control biphasic release of insulin produced by an increase of the glucose concentration from 75 to $150 \mathrm{mg} / \mathrm{dl}$ is shown in Fig. 4 (upper panel). T 20 steadily increased the rate of insulin secretion at $\mathrm{G} 75$, accelerated the response to $\mathrm{G} 150$ and potentiated the effect of glucose $(23.4 \pm 0.9 \mathrm{ng} / 60 \mathrm{~min}$ per islet vs. $19.0 \pm 1.1 \mathrm{ng} / 60 \mathrm{~min}$ per islet in controls, $\mathrm{P}$ $<0.025)$. In the presence of $\mathrm{T} 100$, the insulin response to glucose was markedly changed (Fig. 4, lower panel). The rapid phase of secretion was sup- pressed and the rate of release rose progressively; total insulin release over $60 \mathrm{~min}$ was reduced $(10.9 \pm$ 1.0 ng per islet, $\mathrm{P}<0.005$ ) as compared to controls $(19.0 \pm 1.1 \mathrm{ng}$ per islet). By contrast, if the islets were first stimulated with T 100 for only $5 \mathrm{~min}$ and then washed, for $25 \mathrm{~min}$, in G 75 alone, a biphasic release of insulin was triggered by $\mathrm{G} 150$ with a rapid phase ( $\min 30.5-36$ ) even higher than in controls (1.07 \pm 0.06 vs. $0.54 \pm 0.05 \mathrm{ng}$ per islet, $\mathrm{P}<0.005$ ).

The delayed inhibition by tolbutamide of the insulin response to glucose could not be overcome by a higher concentration of the sugar $(300 \mathrm{mg} / \mathrm{dl})$ and addition of theophylline to $\mathrm{G} 300$ failed to restore a rapid phase of secretion although it normalized the late phase (Fig. 5).

\section{Effect of Tolbutamide on Glucose Utilization by Islet Cells}

As sulphonylureas may not be devoid of metabolic effects in islet cells [6], glucose utilization was evaluated under the present experimental conditions. After preincubation for $30 \mathrm{~min}$ in $\mathrm{G} 75$ alone or with T 20 or T 100 , islets were incubated for $1 \mathrm{~h}$ in $\mathrm{G} 150$ alone or with T 20 or T 100 and glucose metabolism was measured. Glucose utilization was not different in controls $(87.7 \pm 2.8 \mathrm{pmol} /$ islet $)$ and in the presence of T $20(83.2 \pm 2.5 \mathrm{pmol} / \mathrm{islet})$ or T $100(80.1 \pm$ $3.9 \mathrm{pmol} /$ islet $)(\mathrm{n}=10)$.

\section{Effects of Tolbutamide on Calcium Uptake by Islet Cells}

The kinetics of calcium influx in islet cells in response to tolbutamide was estimated by measuring ${ }^{45} \mathrm{Ca}$ 

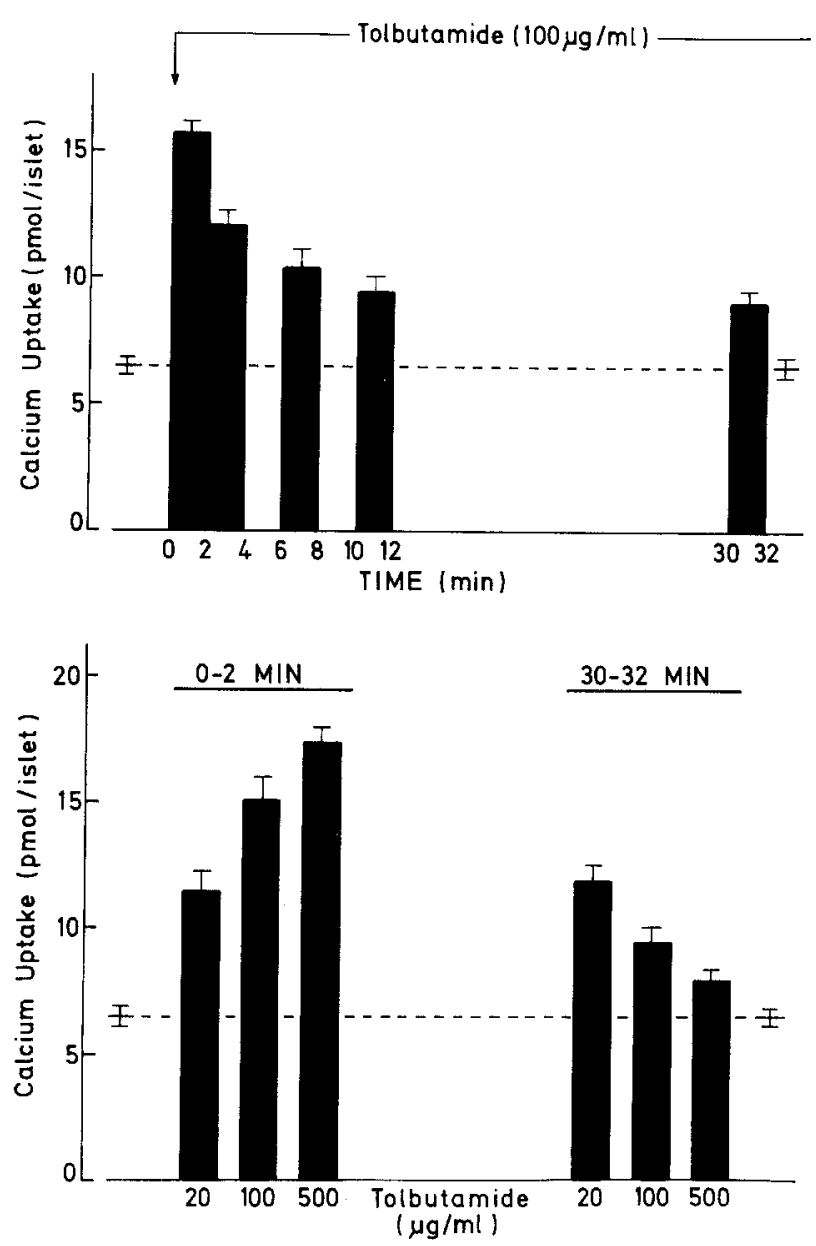

Fig. 6. Effect of tolbutamide on calcium uptake by rat islet cells. After preliminary incubation, for $30 \mathrm{~min}$, in the presence of $75 \mathrm{mg}$ glucose/dl, groups of 10 islets were incubated in $50 \mu \mathrm{l}$ medium containing the indicated concentration of tolbutamide and layered on silicone oil. At different times after the start of the incubation with tolbutamide, $50 \mu \mathrm{l}$ medium with the same concentration of sulphonylurea and glucose, but supplemented with ${ }^{45} \mathrm{CaCl}_{2}$ and $\left[{ }^{3} \mathrm{H}\right]$ sucrose was added to the tubes. After two minutes the islets were centrifuged through the oil. For the period $0-2 \mathrm{~min}$, tolbutamide was added to the islets with ${ }^{45} \mathrm{CaCl}_{2}$. The horizontal broken lines correspond to the control 2 min uptake of calcium by islets incubated in $75 \mathrm{mg}$ glucose/dl without tolbutamide. Values are means \pm SEM of 13 to 16 observations in upper panel and of 10 observations in lower panel

uptake over periods of $2 \mathrm{~min}$, at different times after addition of the sulphonylurea to the islets. T 100 stimulated calcium influx maximally during the first 2 minutes of presence of the drug; the effect declined later, but remained significantly higher than in controls even after $30 \mathrm{~min}$ (Fig. 6, upper panel). The immediate and late effects of tolbutamide $(20-500 \mu \mathrm{g} / \mathrm{ml})$ on calcium uptake are compared in the lower panel of Figure 6. The amount of calcium taken up by islet cells during the first 2 min of tolbutamide stimulation increased with the concentration of the sulphonylurea. By contrast, after $30 \mathrm{~min}$,

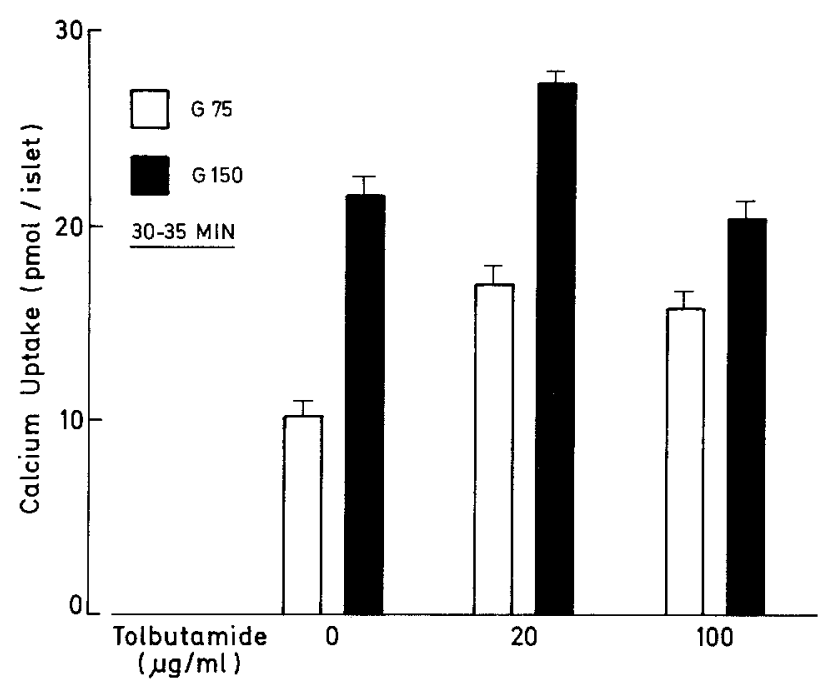

Fig. 7. Effect of tolbutamide on glucose-stimulation of calcium uptake by rat islet cells. After preliminary incubation, for $30 \mathrm{~min}$, in the presence of $75 \mathrm{mg}$ glucose/dl, groups of 10 islets were transferred into $50 \mu \mathrm{l}$ medium containing no, 20 or $100 \mu \mathrm{g}$ tolbutamide/ $\mathrm{ml}$ and $75 \mathrm{mg}$ glucose/dl, and layered on silicone oil. After $30 \mathrm{~min}$ of incubation, $50 \mu \mathrm{l}$ medium with the same concentration of tolbutamide, but supplemented with ${ }^{45} \mathrm{CaCl}_{2}$ and $\left[{ }^{3} \mathrm{H}\right]$ sucrose was added to the tubes. This medium contained $75 \mathrm{mg}$ glucose/dl or $225 \mathrm{mg} / \mathrm{dl}$ (to bring the final concentration to $150 \mathrm{mg} / \mathrm{dl}$ ). After $5 \mathrm{~min}$ the islets were centrifuged through the oil. Values are means \pm SEM of 15,9 and 12 observations at T0, T 20 and T 100 , respectively

calcium uptake was inversely related to the concentration of tolbutamide.

\section{Effect of Tolbutamide}

on Glucose-stimulated Calcium Uptake by Islet Cells

Calcium uptake was measured during the first $5 \mathrm{~min}$ (min 30-35) of exposure to G 150 and compared to the uptake recorded at $G 75$, in control islets $(G 75$ alone from min $0-30$ ) and in islets initially incubated for $30 \mathrm{~min}$ in $\mathrm{G} 75$ with $\mathrm{T} 20$ or 100 . As compared to G 75, G 150 augmented calcium uptake by $110 \%$ in $\mathrm{T} 0,62 \%$ in $\mathrm{T} 20$ and $28 \%$ in T 100 (Fig. 7 ). The relative effect of $\mathrm{G} 150$ was thus decreased by increasing concentrations of tolbutamide. The total amount of calcium taken up by the islets in $\mathrm{G} 150+$ T 20 was, however, higher than in controls at G 150 alone $(\mathrm{P}<0.001)$ whereas, at $\mathrm{G} 150+\mathrm{T} 100$, it was not different from controls.

\section{Effect of Tolbutamide on ${ }^{86} \mathrm{Rb}{ }^{+}$Efflux from Islet Cells}

At $\mathrm{G} 75$, $\mathrm{T} 100$ reversibly reduced ${ }^{86} \mathrm{Rb}^{+}$efflux from preloaded islets (Fig. 8). At G 150, the rate of efflux was lower and addition of $\mathrm{T} 100$ produced a transient increase in ${ }^{86} \mathrm{Rb}^{+}$efflux; no effect was seen upon 

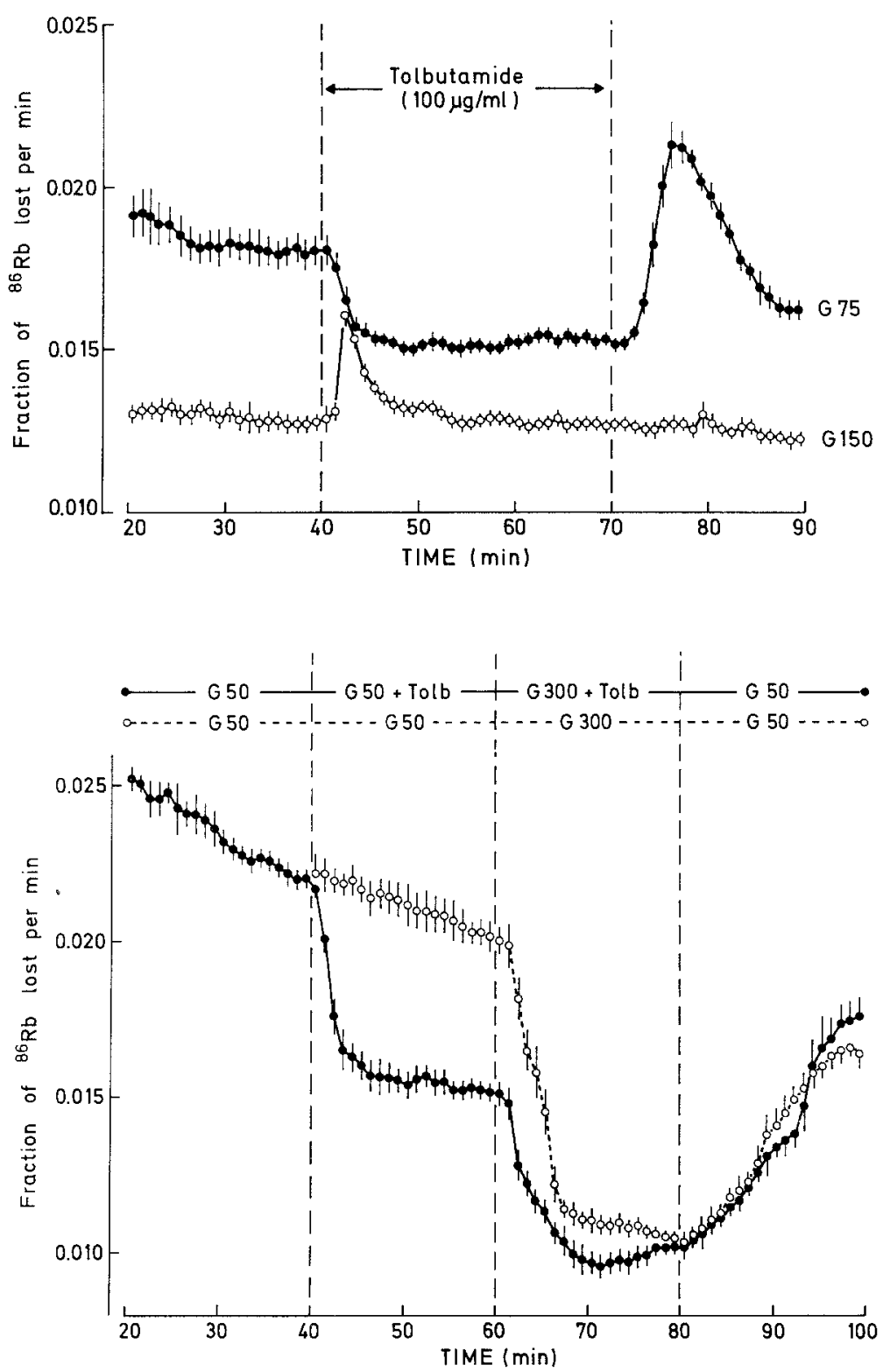

Fig. 8. Effect of tolbutamide $(100 \mu \mathrm{g} / \mathrm{ml})$ on the rate of ${ }^{86} \mathrm{Rb}^{+}$efflux from rat islets perifused in the presence of 75 or $150 \mathrm{mg}$ glucose/d, as indicated in the right part of the Figure. Effluent fractions were collected at intervals of $1 \mathrm{~min}$. Values are means \pm SEM of 5 experiments at $\mathrm{G} 75$ and of 4 experiments at $\mathrm{G} 150$
Fig. 9. Effect of tolbutamide on glucose inhibition of ${ }^{86} \mathrm{Rb}^{+}$efflux from perifused rat islets. The glucose concentration was increased from 50 to $300 \mathrm{mg} / \mathrm{dl}$ between $\min 60$ and 80 . In one series of experiments $(-)$ tolbutamide $(100 \mu \mathrm{g} / \mathrm{ml})$ was also present in the medium from min 40 to 80 . Effluent fractions were collected at intervals of $1 \mathrm{~min}$. Values are means \pm SEM of 4 experiments withdrawal of the sulphonylurea at this glucose concentration.

As shown in Figure 9, the fractional efflux of ${ }^{86} \mathrm{Rb}^{+}$declined slowly at $\mathrm{G} 50$ and was markedly and reversibly reduced by G 300 . Addition of T 100 to G 50 decreased and stabilized the efflux rate and did not prevent $\mathrm{G} 300$ from reducing it further. It is noteworthy that the first significant change in efflux was recorded $1 \mathrm{~min}$ earlier with $\mathrm{T} 100$ than with G 300 .

\section{Discussion}

It has been reported that sulphonylureas do not penetrate $\mathrm{B}$ cells, but reversibly bind to the plasma membrane [23, 24]. They produce permanent depolarization of $\mathrm{B}$ cells and induce continuous electrical activity $[25,26]$; both are reversible upon withdrawal of tolbutamide (H.P. Meissner, personal communication). The present results show that tolbutamide reduces ${ }^{86} \mathrm{Rb}^{+}$efflux from islet cells and suggest therefore that, like glucose [21], the sulphonylurea depolarizes $\mathrm{B}$ cells by reducing their potassium permeability. It is likely, however, that this is not the sole modification of ionic fluxes by which the drug decreases the membrane potential. A permanent depolarization of $\mathrm{B}$ cells, as produced by tolbutamide, is seen only at high glucose concentrations [27] which reduce the potassium permeability more strongly than does the sulphonylurea (Fig. 9). Moreover, the characteristics of the electrical activity 
produced by sulphonylureas and by glucose differ $[25,26]$.

The requirement of extracellular $\mathrm{Ca}^{2+}$ for tolbutamide to stimulate insulin release is well established [28]. Blockade of calcium channels by $\mathrm{D} 600$ inhibits the releasing effect [29] of sulphonylureas, which have been shown to increase $\mathrm{Ca}^{2+}$ uptake by islet cells after long ( $90-120 \mathrm{~min})$ incubation periods $[30,31]$. The present experiments demonstrate that tolbutamide stimulates $\mathrm{Ca}^{2+}$ influx in islet cells (the 2-min uptake being representative mainly of the inward movement of the cation). Two important features of this stimulation of $\mathrm{Ca}^{2+}$ influx by tolbutamide deserve particular attention, because they also characterize the releasing effect of the drug: 1 ) it is maximal immediately after addition of tolbutamide and then diminishes with time; 2) it is directly dosedependent during the first minutes of exposure to tolbutamide but later becomes inversely dose-dependent. Like potassium depolarization (J. C. Henquin, unpublished work), the depolarization produced by tolbutamide appears to increase the permeability of voltage-dependent calcium channels in the B cell membrane. As in squid axons [32], this initial activation is followed by a progressive inactivation of the channels, making the increase in $\mathrm{Ca}^{2+}$ influx only transient. Repolarization of B cells (by withdrawal of tolbutamide) or temporary displacement of calcium from the channel (by omission of the cation or addition of its antagonist, cobalt) reactivate the calcium channels in B cells and in axons [32], and restore the releasing properties of tolbutamide. It is unlikely that reactivation of the calcium channels results from a reduction in tolbutamide binding, since binding of sulphonylureas to islet cells is unaffected by $\mathrm{Ca}^{2+}$ omission from a salt-balanced medium [33]. It seems rather that calcium itself, together with depolarization, is involved in the inactivation of the $\mathrm{Ca}^{2+}$ uptake mechanism [34]; involvement of $\mathrm{Ca}^{2+}$ in the depolarizing effect of tolbutamide is also possible. These observations combined with the striking parallelism between the patterns of $\mathrm{Ca}^{2+}$ influx and insulin release in response to tolbutamide provide good evidence that the classical monophasic release of insulin triggered by high concentrations of the drug, at low glucose, is due to a monophasic entry of $\mathrm{Ca}^{2+}$ into $\mathrm{B}$ cells.

The present data cannot rule out that tolbutamide produces a subtle impairment of glucose recognition by islet cells. It seems plausible, however, that the effects of tolbutamide on glucose-stimulated insulin release are linked to the changes in $\mathrm{Ca}^{2+}$ permeability that the drug produces in B cells. At low concentrations, tolbutamide does not inactivate calcium channels and glucose remains able to increase $\mathrm{Ca}^{2+}$ influx sufficiently to trigger a rapid release of insulin. In the presence of high concentrations of tolbutamide, glucose is no longer able to augment the permeability of calcium channels enough to induce the normal biphasic release of insulin. If $B$ cells were repolarized by withdrawal of tolbutamide, glucose evoked a biphasic insulin response. In contrast, addition of theophylline to glucose normalized only the late phase of secretion, but did not restore the missing first phase. Such a differential effect of the methylxanthine on the two phases of secretion is also observed when glucose stimulation is inhibited by calcium omission or by blockade of calcium entry with D 600 [35]. This similarity provides additional support to the proposal that the rapid releasing effect of glucose is altered after exposure of the islets to a high concentration of tolbutamide because the drug has reduced the calcium permeability of the $\mathrm{B}$ cell membrane.

The suggestion that cyclic-AMP is involved in the stimulation of insulin release by sulphonylureas is based on the evidence that these drugs transiently increase cyclic-AMP levels in islet cells $[36,37]$ by stimulating adenylate cyclase [16] or inhibiting phosphodiesterase [38, 39], two observations made in homogenates of islet cells. In the present experiments, inhibition of the phosphodiesterase by theophylline was able to increase the rate of insulin release when the stimulating effect of tolbutamide had declined. This potentiation was inversely related to the concentration of sulphonylurea, markedly dependent on the availability of extracellular calcium and directly related to the actual $\mathrm{Ca}^{2+}$ influx. It is therefore unlikely that the inhibition of phosphodiesterase (if it occurs in intact islet cells) is of major importance for the releasing effect of tolbutamide. Moreover, the observation that sulphonylureas do not increase cyclic-AMP levels in islet cells when extracellular calcium has been omitted [37] raises the possibility that the increase in cellular cyclic-AMP levels is secondary to the changes in calcium influx.

Impressive similarities exist between the effects of tolbutamide and high potassium $[34,40]$ on the pancreatic $B$ cell and, as recently underlined also on the A cell [8]. Both depolarize B cells permanently but induce only a transient increase in calcium influx and short-lived release, and inhibit the rapid secretion of insulin in response to a subsequent glucose stimulation. Furthermore, stimulation by one of these agents suppresses the insulin response to a subsequent stimulation by the other. On the basis of available data, mentioned above, and of the present experiments, it is suggested that, at low glucose concentrations, tolbutamide stimulates insulin release by the following simple mechanism. Binding of the drug 
to the membrane depolarizes $\mathrm{B}$ cells, partially by reducing the potassium permeability. This fall in membrane potential activates voltage-dependent calcium channels and secondarily inactivates them slowly, at a rate and to an extent which depend on the concentration of the drug. In response to high concentrations of tolbutamide, the phasic increase in calcium permeability results in a transient influx of the ion, which triggers the monophasic release of insulin. The delayed reduction in calcium permeability may also explain the refractoriness of B cells to a subsequent glucose stimulation. The basis of the interaction between glucose and tolbutamide, not investigated here, remains, however, to be clarified. In particular, it is not clear why neither tolbutamide, nor high potassium [40] produced a delayed inhibition of insulin release when added with or after a stimulating concentration of glucose.

It may be hazardous to correlate in vitro findings with observations made in vivo. Nevertheless, the concentrations of tolbutamide from 20 to $100 \mu \mathrm{g} / \mathrm{ml}$, usually used in this study, cover the range in treated patients [41], even if the proportion of free sulphonylurea may be somewhat lower in vivo because of a higher binding to plasma proteins. There is no evident reason to believe that the mechanism by which tolbutamide acutely stimulates insulin release in vivo is different from that proposed above. It is less certain whether the present demonstration of a delayed inhibition of insulin release by tolbutamide provides the sole explanation for the surprising decreased responsiveness of the islets after long-term treatment of animals with sulphonylureas [13-15].

Acknowledgements. The author expresses this thanks to Miss M. Nenquin, Mrs B. Debie and Miss M.-A. Bertrand for devoted assistance, to Mrs. M. Detaille and Miss M. Nenquin for secretarial help and to Prof. A. E. Lambert for reading the manuscript. The author is "Chargé de Recherches" of the Fonds National de la Recherche Scientifique, Brussels.

This study was supported by grant 3.4509 .75 from the Fonds de la Recherche Scientifique Médicale, Brussels and by a grant-inaid from Hoechst-Belgium S.A.

\section{References}

1. Loubatières A (1957) The hypoglycemic sulfonamides: history and development of the problem from 1942 to 1945 . Ann N Y Acad Sci 71: 4-11

2. Yalow R S, Black H, Villazon J, Berson S A (1960) Comparison of plasma insulin levels following administration of tolbutamide and glucose. Diabetes 9: 356-362

3. Seltzer H S (1962) Quantitative effects of glucose, sulfonylureas, salicylate, and indole-3-acetic acid on the secretion of insulin activity into pancreatic venous blood. $\mathbf{J}$ Clin Invest 41 : 289-300

4. Bouman P R, Goorenstroom J H (1961) Stimulation by carbutamide and tolbutamide of insulin release from rat pancreas in vitro. Metabolism 10: 1095-1099
5. Grodsky G M, Schmid F G, Manning M, Fanska R (1973) Comparison of the independent and interrelated effects of glucose and sulfonylureas on insulin release in the perfused pancreas. In: Okita G T, Acheson G M (eds) Pharmacology and the future of man: Proc. 5th Int. Congr. Pharmacology. Vol. 3: Problems of therapy. Karger, Basel, p 230-238

6. Hellman B, Täljedal I-B (1975) Effects of sulfonylurea derivatives on pancreatic $B$ cells. In: Hasselblatt $A$, von Bruchausen F (eds) Insulin II. Springer, Berlin Heidelberg New York, p 175-194

7. Loubatières A (1977) Effects of sulfonylureas on the pancreas. In: Volk B W, Wellmann K E (eds) The diabetic pancreas. Baillière Tindall, London, p 489-515

8. Grodsky G M, Epstein G H, Fanska R D, Karam J H (1977) Pancreatic action of the sulfonylureas. Fed Proc 36: 2714-2719

9. Sheldon J, Taylor K W, Anderson J (1965) The effects of long term acetohexamide treatment on pancreatic islet cell function in maturity-onset diabetes. Metabolism 15: 874-883

10. Reaven G, Dray J (1967) Effect of chlorpropamide on serum glucose and immunoreactive insulin concentrations in patients with maturity-onset diabetes. Diabetes 15: 487-492

11. Chu P-C, Conway J J, Krouse H A, Goodner C J (1968) The pattern of response of plasma insulin and glucose to meals and fasting during chlorpropamide therapy. Ann Intern Med 68: 757-769

12. Sussman K E, Stjernholm M, Vaughan G D (1967) Tolbutamide and its effect upon insulin secretion in the isolated perfused rat pancreas. In: Butterfield $\mathrm{W} \mathrm{J} \mathrm{H}$, von Westering $\mathrm{W}$ (eds) Tolbutamide after ten years. Excerpta Medica, Amsterdam, p 22-33

13. Sodoyez J-C, Sodoyez-Goffaux F, Dunbar J C, Foa P P (1970) Reduction in the activity of the pancreatic islets induced in normal rodents by prolonged treatment with derivatives of sulfonylurea. Diabetes 19: 603-609

14. Dunbar J C, Foa P P (1974) An inhibitory effect of tolbutamide and glibenclamide (glyburide) on the pancreatic islets of normal animals. Diabetologia 10: 27-35

15. Schauder P, Arends J, Frerichs H (1977) Onset and reversibility of changes in secretory function and composition of isolated rat pancreatic islets following long-term administration of high and low tolbutamide doses. Metabolism 26: 9-15

16. Kuo W-N, Hodgins D S, Kuo J F (1973) Adenylate cyclase in islets of Langerhans. Isolation of islets and regulation of adenylate cyclase activity by various hormones and agents. $\mathrm{J}$ Biol Chem 248: 2705-2711

17. Henquin J C, Lambert A E (1975) Cobalt inhibition of insulin secretion and calcium uptake by isolated rat islets. Am J Physiol 228: 1669-1677

18. Ashcroft S J H, Weerasinghe L C C, Bassett J M, Randle P J (1972) The pentose cycle and insulin release in mouse pancreatic islets. Biochem J 126: 525-532

19. Henquin J C, Lambert A E (1976) Bicarbonate modulation of glucose-induced biphasic insulin release by rat islets. Am J Physiol 231: 713-721

20. Henquin J C (1977) Tetraethylammonium potentiation of insulin release and inhibition of rubidium efflux in pancreatic islets. Biochem Biophys Res Commun 77: 551-556

21. Henquin J C (1978) D-glucose inhibits potassium efflux from pancreatic islet cells. Nature 271: 271-273

22. Hellman B, Sehlin J, Täljedal I-B (1971) Evidence for mediated transport of glucose in mammalian pancreatic B cells. Biochim Biophys Acta 241: 147-154

23. Hellman B, Sehlin J, Täljedal I-B (1971) The pancreatic B-cell recognition of insulin secretagogues. II. Site of action of tolbutamide. Biochem Biophys Res Commun 45: 1384-1388

24. Hellman B, Sehlin J, Täljedal I-B (1973) The pancreatic B-cell 
recognition of insulin secretagogues. IV. Islet uptake of sulfonylurea. Diabetologia 9: 210-216

25. Matthews E K, Dean P M, Sakamoto Y (1973) Biophysical effects of sulfonylurea on islet cells. In: Okita G T, Acheson G $M$ (eds) Pharmacology and the future of man: Proc. 5th Int. Congr. Pharmacology. Vol. 3: Problems of therapy. Karger, Basel, p 221-229

26. Meissner H P, Atwater I J (1976) The kinetics of electrical activity of beta cells in response to a "square wave" stimulation with glucose or glibenclamide. Horm Metab Res 8: 11-16

27. Meissner H P (1976) Electrical characteristics of the beta cells in pancreatic islets. J Physiol (Paris) 72: 757-767

28. Curry D L, Bennett L L, Grodsky G M (1968) Requirement for calcium ion in insulin secretion by the perfused rat pancreas. Am J Physiol 214: 174-178

29. Malaisse W J, Devis G, Pipeleers D G, Somers G (1976) Calcium-antagonists and islet function. IV. Effect of D 600 . Diabetologia 12: 77-81

30. Malaisse W J, Mahy M, Brisson G R, Malaisse-Lagae F (1972) The stimulus-secretion coupling of glucose-induced insulin release. VIII. Combined effects of glucose and sulfonylureas. Eur J Clin Invest 2: 85-90

31. Hellman B, Lenzen S, Sehlin J, Täljedal I-B (1977) Effects of various modifiers of insulin release on the lanthanum-nondisplaceable ${ }^{45} \mathrm{Ca}^{2+}$ uptake by isolated pancreatic islets. Diabetologia 13: 49-53

32. Baker P F, Meves H, Ridgway E B (1973) Calcium entry in response to maintained depolarization of squid axons. J Physiol (Lond) 231: 527-548

33. Hellman B (1974) Factors affecting the uptake of glibenclamide in microdissected pancreatic islets rich in $\beta$ cells. Pharmacology 11: 257-267

34. Henquin J C, Lambert A E (1976) Insulin secretion during B cell depolarization with potassium (Abstract). Diabetes 25 (Suppl 1): 345
35. Henquin J C (1978) Relative importance of extracellular and intracellular calcium for the two phases of glucose-stimulated insulin release: studies with theophylline. Endocrinology 102: 723-730

36. Charles M A, Lawecki J, Steiner A L, Grodsky G M (1976) Cyclic nucleotides in pancreatic islets. Tolbutamide and arginine-induced insulin release. Diabetes 25: 256-259

37. Grill V, Cerasi E (1978) Interacting effects of sulfonylureas and glucose on cyclic AMP metabolism and insulin release in pancreatic islets of the rat. J Clin Invest 61: 1346-1354

38. Sams D J, Montague W (1972) The role of adenosine 3', 5'monophosphate in the regulation of insulin release. Properties of islet-cell adenosine 3',-5'cyclic monophosphate phosphodiesterase. Biochem J 129: 945-952

39. Ashcroft S J H, Randle P J, Täljedal I-B (1972) Cyclic nucleotide phosphodiesterase activity in normal mouse pancreatic islets. FEBS Lett 20: 263-266

40. Henquin J C, Lambert A E (1974) Cationic environment and dynamics of insulin release. II. Effect of a high concentration of potassium. Diabetes 23: 933-942

41. Braselton W E, Bransome E D, Huff T A (1977) Measurement of antidiabetic sulfonylureas in serum by gas chromatography with electron-capture detection. Diabetes 26: 50-57

Received: February 26, 1979, and in revised form: June 13, 1979

Dr. J.-C. Henquin

Unité de Diabète et Croissance

University of Louvain, UCL 54.74

B-1200 Brussels

Belgium 